\title{
Activin-Directed Differentiation of Human Embryonic Stem Cells Differentially Modulates Alveolar Epithelial Wound Repair via Paracrine Mechanism
}

\author{
Khondoker M. Akram1, Monica A. Spiteri ${ }^{1,2}$, Nicholas R. Forsyth ${ }^{*}$ \\ ${ }^{1}$ Institute for Science and Technology in Medicine, School of Postgraduate Medicine, Keele University, \\ Stoke-on-Trent, UK \\ ${ }^{2}$ Department of Respiratory Medicine, University Hospital of North Staffordshire, Stoke-on-Trent, \\ UK \\ Email: ${ }^{*}$.r.forsyth@keele.ac.uk
}

Received 1 April 2014; revised 1 May 2014; accepted 30 May 2014

Copyright $@ 2014$ by authors and Scientific Research Publishing Inc.

This work is licensed under the Creative Commons Attribution International License (CC BY). http://creativecommons.org/licenses/by/4.0/

(c) (;) Open Access

\section{Abstract}

Differentiated embryonic stem cells (ESC) can ameliorate lung inflammation and fibrosis in animal lung injury models; therefore, ESC, or their products, could be candidates for regenerative therapy for incurable lung diseases, such as idiopathic pulmonary fibrosis (IPF). In this study, we have investigated the paracrine effect of differentiated and undifferentiated human ESC on alveolar epithelial cell (AEC) wound repair. hESC line, SHEF-2 cells were differentiated with Activin treatment for 22 days in an embryoid body (EB) suspension culture. Conditioned media (CM) which contain cell secretory factors were collected at different time points of differentiation. CM were then tested on in vitro wound repair model with human type II AEC line, A549 cells (AEC). Our study demonstrated that CM originated from undifferentiated hESC significantly inhibited AEC wound repair when compared to the control. Whereas, CM originated from Activin-directed hESC differentiated cell population demonstrated a differential reparative effect on AEC wound repair model. CM obtained from Day-11 of differentiation significantly enhanced AEC wound repair in comparison to CM collected from pre- and post-Day-11 of differentiation. Day-11 CM enhanced AEC wound repair through significant stimulation of cell migration and cell proliferation. RT-PCR and immunocytochemistry confirmed that Day-11 CM was originated form a mixed population of endodermal/mesodermal differentiated hESC. This report suggests a putative paracrine-mediated epithelial injury healing mechanism by hESC secreted products, which is valuable in the development of novel stem cell-based therapeutic strategies.

${ }^{*}$ Corresponding author.

How to cite this paper: Akram, K.M., Spiteri, M.A. and Forsyth, N.R. (2014) Activin-Directed Differentiation of Human Embryonic Stem Cells Differentially Modulates Alveolar Epithelial Wound Repair via Paracrine Mechanism. Stem Cell Discovery, 4, 67-82. http://dx.doi.org/10.4236/scd.2014.43008 


\section{Keywords}

\section{Embryonic Stem Cells, Alveolar Epithelial Wound Repair, Idiopathic Pulmonary Fibrosis (IPF), Embryonic Stem Cell-Mediated Paracrine Mechanism, Activin-Directed hESC Differentiation}

\section{Introduction}

Idiopathic pulmonary fibrosis (IPF) is a chronic, progressive fibrosing interstitial pneumonia of unknown aetiology occurring primarily in older adults, and limited to the lungs [1]. The pathophysiological process of this disease is not well understood. According to the recent hypothesis, IPF occurs due to multiple micro-injuries to alveolar epithelial cells (AEC) followed by imbalanced immune response and aberrant alveolar injury repair where inflammation does not play any vital role [2] [3]. Human alveoli are lined with type I and type II AEC, where type II AEC are believed to be progenitors for type I AEC and take part in alveolar epithelial restitution after injury [4]. Following injury, the restoration of alveolar integrity and functionality through rapid epithelial restitution of the denuded alveolar basement membrane through AEC migration, proliferation and differentiation is essential [2] [5]-[7]. In IPF, this healing process appears to be impaired [2]. Whilst the precise mechanism of this aberrant alveolar repair remains uncertain, multifactorial causes including repeated AEC injuries [2] [8], increased AEC apoptosis [9]-[13], dysregulated epithelial-mesenchymal cross-talk [14], polarised immune response [3], alveolar bronchiolisation [13] [15] [16] and recently demonstrated epigenetic dysregulation [17]-[19] are believed to be involved.

At present there is no efficacious treatment for IPF other than lung transplantation. A continuous unsatisfactory outcome of newly developed pharmacological molecules to combat the disease progression, an alternative embryonic stem cell (ESC)-mediated regenerative therapy has been suggested [20]. ESC are self-renewing pluripotent stem cells derived from the inner cell mass of a 5 - 6-day-old blastocyst of an early mammalian embryo and are capable of unlimited, undifferentiated proliferation in vitro. Unlike adult stem cells, ESC are capable of differentiating into tissues of all three germ layers [21]-[23]. Due to this enormous differential potential, ESC has been suggested as potential candidates for regenerative cell therapy for a diverse group of clinical conditions including IPF.

Successful derivation of cardiomyocytes or neuronal cells from ESC has already been described [24]-[28]. Meanwhile, the definitive endodermal lineage differentiation that gives rise to the epithelium of lung, intestine, liver, pancreas, thyroid glands and thymus, has appeared to be more challenging and the protocols are currently evolving [29]. Stimulation of embryoid bodies (EBs), an aggregation of ESC, with serum for 2.5 days followed by a serum-free culture for further 3.5 days increases expression of endodermal genes, Foxa 2 and Sox 17 and simultaneously decreases expression of mesodermal gene, Gata1 and brachyury; whereas, continuous exposure of EBs to serum reduced endodermal gene expression [30]. Furthermore, Activin A (a member of the TGF- $\beta$ super-family proteins) treatment with high concentration $(100 \mathrm{ng} / \mathrm{ml})$ stimulates ESC into definitive endoderm [29]-[31].

The generation of endodermal derivatives from ESC has been demonstrated through differentiation of pancreatic islets [32] [33], hepatocytes [34]-[36], intestinal cells [37] and lung epithelial cells [38] [39]. Type II AEC have been successfully differentiated from human [40] and mouse [38] [39] [41] ESC. More recently, Wang and colleagues have demonstrated that intratracheal administration of ESC-derived type II AEC improved survival and ameliorated pulmonary inflammation and fibrosis in a bleomycin-induced experimental lung injury model [40]. In this study, structural engraftment of transplanted ESC-derived type II AEC and their differentiation into type I AEC were also noted [40]. However, attenuation of bleomycin-induced fibrotic responses occurred as early as 24 to 48 hours post ESC-derived type II AEC administration which indicated a putative paracrine mechanism involved in the amelioration of pulmonary fibrosis. However, the paracrine role of ESC on alveolar repair remains unknown.

In this study, we sought to investigate the paracrine role of undifferentiated and differentiated human ESC (hESC) on AEC injury repair. Accordingly, the conditioned media (CM), which contain the secretome (secretory factors) of cultured hESC, were tested on a widely studied in vitro scratch wound repair model [13] [42] [43]. Here, we have demonstrated that secretory product of Activin-directed differentiated hESC stimulated 
AEC injury repair through both motogenic and mitogenic mechanisms; more interestingly, these effects were only observed with CM collected on the 11th day of ESC differentiation. The secretory products of undifferentiated hESC negatively affected the AEC injury repair. Failure or delayed alveolar epithelial restitution has been suggested as a critical early anomaly that causes IPF; therefore, abrogation of aberrant epithelial restitution could be an effective therapeutic approach. These data will enrich our understanding in hESC-mediated wound healing mechanism towards development of novel stem cell-meditated therapeutic strategies for diverse pulmonary diseases including IPF.

\section{Materials and Methods}

\subsection{Cell Culture}

Human type II alveolar epithelial cell line A549 cells (AEC) were purchased from ATCC, Rockville, USA and cultured in DMEM (Gibco, Invitrogen, USA) supplemented with 10\% FBS (Lonza, Belgium), 1\% L-glutamine (Lonza, Belgium) and 1\% NEAA (Non-essential amino acid) (Lonza, Belgium). Human embryonic cell line SHEF-2 was obtained under license from UK Stem Cell Bank. SHEF-2 cells were cultured on matrigel-coated tissue culture flask using mouse embryonic fibroblasts (MEFs) conditioned media (CM) following a feeder-free culture protocol described by Xu et al. [64]. Briefly, cryopreserved SHEF-2 (P-28 to P-46) cells were thawed and seeded on matrigel (1:100 dilution, BD Matrigel Matrix ${ }^{\mathrm{TM}}$, BD, Bedford, MA, USA; Cat No-354234)coated T-25 tissue culture flasks in MEF-CM. MEF-CM was prepared by culturing KO-DMEM (Gibco, Invitrogen) supplemented with 20\% KO-SR (Knock-out serum replacement, Gibco, Invitrogen), 1\% L-glutamine (Lonza), 1\% NEAA, $0.1 \mathrm{mM} \beta$-mercaptoethanol (Invitrogen) and $4 \mathrm{ng} / \mathrm{ml}$ human bFGF (Basic fibroblast growth factor, Peprotech, USA) for 24 hours on 60\% - 80\% confluent adherent culture of MEFs (isolated from 12.5 to 13.5-day pregnant black CB1 hybrid mice). Before use, MEF-CM was further supplemented with bFGF (4 $\mathrm{ng} / \mathrm{ml}$ ) and sterile filtered using $0.20 \mu \mathrm{m}$ porous Millipore filtration unit (Millipore). Culture surfaces of T25 tissue culture flasks were coated with 1:100 diluted matrigel in ice cold KO-DMEM. $4 \mathrm{ml}$ of ice cold diluted matrigel solution was added into each T25 flask and incubated at room temperature for 2 hours. Before use, matrigel containing flasks were incubated at $37^{\circ} \mathrm{C}$ for 30 minutes in the incubator, after incubation the matrigel media was discarded and hESC culture media was added. SHEF-2 cells were maintained undifferentiated in a continuous culture using the above culture protocol and passed at 1:2 to 1:4 split ratios. All cells were cultured in a humidified tissue culture incubator at $37^{\circ} \mathrm{C}$ in presence of $5 \% \mathrm{CO}_{2}$ and $95 \%$ air.

\subsection{Condition Media Preparation}

CM from undifferentiated hESC: SHEF-2 (P-32) were grown 60\% - 70\% confluent using MEF-CM in T-25 culture flasks. Two sets of media were conditioned which were composed of KO-DMEM with $4 \mathrm{ng} / \mathrm{ml}$ of bFGF $\left(\mathrm{CM}^{\mathrm{bFGF}}\right)$ or without bFGF $\left(\mathrm{CM}^{\mathrm{bFGF}}\right)$, supplemented with $10 \% \mathrm{KO}-\mathrm{SR}, 1 \%$ L-glutamine, $1 \%$ NEAA and 0.1 $\mathrm{mM} \beta$-mercaptoethanol. $6 \mathrm{ml}$ of above media was used to culture undifferentiated SHEF-2 cells in standard culture condition for 24 hours after which media was collected and sterile filtered with $0.20 \mu \mathrm{m}$ porous, $33 \mathrm{~mm}$ cellulose acetate syringe filter prior use. If required, conditioned media were stored at $-20^{\circ} \mathrm{C}$.

Differentiation of hESC and CM preparation: Three different passages of SHEF-2 (P-37, P-38 and P-46) cell were differentiated using FBS (Cat. No-DE14-870F, Lonza, Belgium) followed by Activin A (Cat. No-120-14, Peprotech, USA) (Table 1). Undifferentiated adherent SHEF-2 cells were harvested from 3 T-25 flasks by trypsinisation and seeded on a $10 \mathrm{~cm}$ non-adherent petridish in $20 \mathrm{ml}$ of MEF-CM for 24 hours in a suspension culture allowing cells to form EBs. These EBs then underwent the following steps for differentiation and CM preparation as tabulated below (Table 1). CM was collected at different time points of hESC differentiation and stored at $-20^{\circ} \mathrm{C}$. Prior to use, $\mathrm{CM}$ were sterile filtered by $0.20 \mu \mathrm{m}$ porous cellulose acetate syringe filter.

\subsection{Assessment of hESC Conditioned Media on AEC in Vitro Wound Repair System}

The in vitro wound repair assay was performed following previously published methodology [13]. Briefly, $1.5 \times$ $10^{5}$ A549 cells were seeded into each well of a 24-well plate and cultured to confluence as monolayers over 24 hours in DMEM supplemented with 10\% FBS, 1\% L-glutamine and 1\% NEAA. After wounding cell monolayers were washed twice with PBS and replenished with either $\mathrm{CM}$ of undifferentiated $\mathrm{hESC}\left(\mathrm{CM}^{\mathrm{bFGF}}\right.$ or $\left.\mathrm{CM}^{\mathrm{bFGF}}\right)$ or CM collected from different time-points of differentiated hESC (Day-8 CM, Day-11 CM, Day-16 CM, Day-22 
Table 1. SHEF-2 differentiation protocol through EB culture and CM collection.

\begin{tabular}{|c|c|c|c|c|}
\hline Steps & Culture protocol & Culture media composition & Culture duration & CM labels \\
\hline EB formation & $\begin{array}{l}\text { SHEF-2 cells were pooled from } 3 \\
\text { T25 flasks and seeded in } 10 \mathrm{~cm} \\
\text { non-adherent petridish in } 20 \mathrm{ml} \text { of } \\
\text { MEF-CM. }\end{array}$ & $\begin{array}{c}\text { MEF-CM composed of: } \\
\text { KO-DMEM + 20\% SR + } 8 \mathrm{ng} / \mathrm{ml} \text { bFGF }+0.1 \\
\text { mM } \beta \text {-mercaptoethanol }+1 \% \text { L-glutamine }+ \\
\text { 1\% NEAA. }\end{array}$ & Day 0-1 & - \\
\hline $\begin{array}{l}\text { FBS treatment of } \\
\text { EBs }\end{array}$ & $\begin{array}{l}\text { EBs were collected and cultured } \\
\text { in } 20 \text { ml of } 10 \% \text { FBS } \\
\text { supplemented KO-DMEM. }\end{array}$ & $\begin{array}{c}\text { KO-DMEM }+10 \% \text { FBS }+0.1 \mathrm{mM} \\
\beta \text {-mercaptoethanol }+1 \% \text { L-glutamine }+1 \% \\
\text { NEAA. }\end{array}$ & Day 1-3.5 & - \\
\hline $\begin{array}{l}\text { Activin A } \\
\text { treatment of EBs }\end{array}$ & $\begin{array}{c}\text { EBs were collected and treated } \\
\text { with } 100 \mathrm{ng} / \mathrm{ml} \text { human Activin A. }\end{array}$ & $\begin{array}{c}\text { KO-DMEM + 10\% SR + } 100 \mathrm{ng} / \mathrm{ml} \text { human } \\
\text { Activin A + } 0.1 \mathrm{mM} \beta \text {-mercaptoethanol + 1\% } \\
\text { L-glutamine + 1\% NEAA. }\end{array}$ & Day 3.5-8 & Day-8 CM \\
\hline $\begin{array}{l}\text { EB suspension } \\
\text { culture }\end{array}$ & $\begin{array}{l}\text { EBs were collected and cultured } \\
\text { in KO-DMEM }\end{array}$ & $\begin{array}{c}\text { KO-DMEM }+10 \% \mathrm{SR}+0.1 \mathrm{mM} \\
\beta \text {-mercaptoethanol }+1 \% \text { L-glutamine }+1 \% \\
\text { NEAA. }\end{array}$ & Day 8-11 & Day-11 CM \\
\hline $\begin{array}{l}\text { EB suspension } \\
\text { culture }\end{array}$ & $\begin{array}{l}\text { EBs were collected and cultured } \\
\text { in KO-DMEM. }\end{array}$ & $\begin{array}{c}\text { KO-DMEM }+10 \% \mathrm{SR}+0.1 \mathrm{mM} \\
\beta \text {-mercaptoethanol }+1 \% \text { L-glutamine }+1 \% \\
\text { NEAA. }\end{array}$ & Day 11-16 & Day-16 CM \\
\hline $\begin{array}{l}\text { EB suspension } \\
\text { culture }\end{array}$ & $\begin{array}{l}\text { EBs were collected and cultured } \\
\text { in KO-DMEM. }\end{array}$ & $\begin{array}{c}\text { KO-DMEM }+10 \% \mathrm{SR}+0.1 \mathrm{mM} \\
\beta \text {-mercaptoethanol }+1 \% \text { L-glutamine }+1 \% \\
\text { NEAA. }\end{array}$ & Day 16-22 & Day-22 CM \\
\hline
\end{tabular}

$\mathrm{CM}$ ) as mentioned above. Controls for $\mathrm{CM}^{\mathrm{bFGF}}$ and $\mathrm{CM}^{\mathrm{bFGF}-}$ treated samples were media which was not conditioned (Un-CM ${ }^{\mathrm{bFGF}}$ and $\mathrm{Un}-\mathrm{CM}^{\mathrm{bFGF}-}$ respectively). For positive and negative controls, wounded monolayers were treated with KO-DMEM supplemented with $10 \%$ KO-SR, $1 \%$ L-glutamine and $1 \%$ NEAA, and KO-SR free KO-DMEM, respectively. Wounded AEC monolayers were then incubated for 24 hours in standard culture conditions. Wound images were captured at 0 hour and after 24 hours by a CCD camera (Canon, Japan) equipped with an inverted light microscope (Nikon Eclipse, TS100, Japan). Circumferential wound gaps were then measured by Image J software (NIH, USA) and percentage of wound repair after 24 hours was calculated.

\subsection{Measurement of Internuclear Distances}

To measure the relative migration of AEC during injury repair, internuclear distances between migrated AEC at wound margins were measured after 24 hours of wounding using Image $J$ software. Three measurements were taken per migrated cell which was adjacent to the wound margins. A total 18 measures were recorded per wound.

\subsection{MTT Cell Proliferation Assay}

To evaluate the effects of CM of differentiated hESC, Day-8 CM, Day-11 CM and Day-22 CM on AEC proliferation during wound repair, the MTT (3-(4,5-dimethylthiazol-2-yl)-2,5-diphenyltetrazolium bromide) cell proliferation assay was performed using the MTT reagent Thiazolyl Blue Tetrazolium Bromide (Sigma, Cat NoM5655) following manufacturer's instructions [65]. Briefly, $10^{5}$ A549 cells were grown to confluence on each well of a 48-well plate over 24 hours and wounds made as described above. For a 0 hour reading, MTT was performed immediately after wounding. Wounded monolayers were washed and $300 \mu \mathrm{l}$ of $0.5 \mathrm{mg} / \mathrm{ml}$ MTT reagent containing serum-free (SF) KO-DMEM added to each well and incubated at $37^{\circ} \mathrm{C}$ for 2 hours. After incubation, MTT solution was discarded and washed twice with pre-heated PBS. Formazan was extracted with $100 \%$ DMSO $(250 \mu \mathrm{l} /$ well $)$ incubation for 10 minutes in the incubator at $37^{\circ} \mathrm{C} .200 \mu \mathrm{l}$ of extracted formazan-DMSO solution was then loaded in each well of 96-well plate and absorption measured with a micro-plate reader (BioTek, Synergy 2) at a $630 \mathrm{~nm}$ wavelength. For 24 hours readings, wounded AEC monolayers were treated with either Day-8 CM, Day-11 CM, Day-22, positive and negative control media for 24 hours in the incubator at $37^{\circ} \mathrm{C}$ with standard culture condition. After 24 hours of incubation, media was discarded and the MTT assay performed as above. Triplicate experiments were performed for each sample. Data presented as percentage increase of optical density (OD) reflecting degree of cell proliferation after 24 hours. 


\subsection{RT-PCR Analysis}

RT-PCR was performed to evaluate Oct-4, Nanog, hTERT mRNA expression in undifferentiated hESC; and AFP, ACTC1 and SOX1 in differentiated suspension culture of EBs. Total RNA was extracted using RNeasy Mini Spin Column (Cat. No-74104, Qiagen, Germany) according to the manufacturer protocol. Quality and quantity of yield RNA were determined by measurement of absorption at 260 and $280 \mathrm{~nm}$ using NanoDrop ND-1000 spectrophotometer (NanoDrop, USA). The ratio of optical density at 260 and $280 \mathrm{~nm}$ was $>1.8$ in all samples. One-step RT-PCR was performed using SuperScript ${ }^{\circledR}$ III One-Step RT-PCR System with Platinum ${ }^{\circledR}$ Taq High Fidelity kit (Cat. No-12574-035, Invitrogen, CA, USA) and amplified in DNA Engine ${ }^{\circledR}$ Thermal Cycler (MJ Research, MA, USA) in a single tube according to the manufacturer protocol. In short, 10 ng RNA of each sample was mixed with $6.25 \mu \mathrm{l} 2 \mathrm{X}$ Reaction Mix, $3 \mu \mathrm{l}$ RNAse-free water, $1 \mu \mathrm{l}$ of each primer $(10 \mu \mathrm{M})$ and $0.25 \mu \mathrm{l}$ of Platinum ${ }^{\circledR} \mathrm{Taq}$ polymerase enzyme. The thermal cycling protocol comprised an initial reverse transcription at $50^{\circ} \mathrm{C}$ for 30 minutes, pre-denaturation at $94^{\circ} \mathrm{C}$ for 2 minutes followed by 30 cycles of denaturation at $94^{\circ} \mathrm{C}$ for 15 seconds, annealing at $53^{\circ} \mathrm{C}-56^{\circ} \mathrm{C}$ (depending on primers) (Table 2) for 30 seconds and extension at $68^{\circ} \mathrm{C}$ for 1 minute followed by a final extension at $64^{\circ} \mathrm{C}$ for 5 minutes. The PCR fragments were separated by electrophoresis on $2 \%$ agarose gel (Fisher Scientific, NJ, USA) and visualized by staining with ethidium bromide (Cat. No-E1510, Sigma, MO, USA) under UV light. $\beta$-actin was used as a loading control. All primers were obtained from Invitrogen, USA (Table 2).

\subsection{Fluorescence Immunocytochemistry}

$2.5 \times 10^{4}$ SHEF-2 (P-44) cells were plated into each well of a 48-well plate and grown to $60 \%$ - $70 \%$ confluency for evaluation of hESC pluripotent markers by immunocytochemistry. Cells were fixed with $4 \%$ paraformaldehyde (PFA) (Fisher Scientific, UK) for 30 minutes, permeabilised with 0.5\% Triton-X 100 (Sigma) for 5 minutes and blocked with 3\% BSA (Sigma) for 1 hour at room temperature (RT). Fixed SHEF-2 cells were characterised using the "Human Embryonic Stem Cell Marker Antibody Panel" kit containing anti-human mouse anti-alkaline phosphatase (ALP), anti-SSEA-1, anti-SSEA-4, goat anti-Oct-4, anti-Nanog primary antibodies at $1 \mu \mathrm{g} / 100 \mu \mathrm{l}$ concentration (Cat. No. SC008, R \& D System). Cells were incubated with primary antibodies at $4^{\circ} \mathrm{C}$ for 24 hours. Secondary antibodies were anti-goat IgG-NL493 (1:200, NorthernLights, R \& D System) for Oct-4 and Nanog; and TRITC-conjugated anti-mouse IgG (1:200, ab6787, Abcam) for ALP, SSEA-1 and SSEA-4. Secondary antibody treatment was for 2 hours at RT. EBs were collected on Day-1 and Day-11 during differentiation for immunocytochemistry. Approximately 100 EBs were taken in each well for each antibody and fixed with 4\% PFA for 1 hour, permeabilised with $0.5 \%$ Triton X-100 for 20 minutes and then washed twice with PBS. EBs which were subject for visualisation with donkey secondary antibody were blocked with 3\% BSA and 1\% donkey serum; and those EBs which were subject for visualisation with goat secondary antibody were blocked with 3\% BSA and 1\% goat serum for 2 hours at RT. EBs were then incubated with Human Embryonic Stem Cell Marker Antibody Panel kit as described above. Secondary antibody treatment was as above. DAPI was used for nuclear staining. Images were acquired by a fluorescent microscope (Nikon Eclipse Ti-ST, Japan).

\subsection{Statistical Analysis}

The significance of difference between groups was determined by one-way ANOVA with Newman-Keuls Multiple Comparison Posthoc Analysis. A "p" value less than 0.05 was considered to indicate statistical significant. Data are presented as mean \pm standard deviation (SD). All statistical analysis was performed using GraphPad Prism version 5.00 software (GraphPad Software, San Diego, California, USA).

\section{Results}

\subsection{Undifferentiated hESC Secretome Inhibits AEC Wound Repair}

The hESC line, SHEF-2 displayed high levels of hTERT gene expression and were also positive for pluripotent nuclear markers Octamer-binding protein-4 (Oct-4) (also know as POU domain, class 5, transcription factor 1, POU5F1) and Nanog (also know as Homeobox protein NANOG) detected by RT-PCR (Figure 1(a)) and immunocytochemistry (Figure 1(b)) [44]-[47]. SHEF-2 cells were positive for both alkaline phosphatase (ALP) and stage-specific embryonic antigen-4 (SSEA-4) markers [44] [45] (Figure 1(b)). To investigate the effect of the 
Table 2. Primer sequences. Official name is listed in gene column with alternative name in parentheses. Forward (F) and reverse $(\mathrm{R})$ primers are listed in 5' to 3' orientation.

\begin{tabular}{|c|c|c|c|c|}
\hline Genes & & Primers (5'-3') & Annealing temp $\left({ }^{\circ} \mathrm{C}\right)$ & Amplicon size (bp) \\
\hline \multirow{2}{*}{ POU5F1 (Oct-4) } & $\mathbf{F}$ & GCAATTTGCCAAGCTCCTGAAGCAG & \multirow{2}{*}{55} & \multirow{2}{*}{536} \\
\hline & $\mathbf{R}$ & CATAGCCTGGGGTACCAAAATGGGG & & \\
\hline \multirow{2}{*}{ NANOG (Nanog) } & $\mathbf{F}$ & GGTGGCAGAAAAACAACTGGC & \multirow{2}{*}{55} & \multirow{2}{*}{300} \\
\hline & $\mathbf{R}$ & TGCAGGACTGCAGAGATTCC & & \\
\hline \multirow{2}{*}{ TERT (hTERT) } & $\mathbf{F}$ & GCAGCTCCСATTTCATCAGC & \multirow{2}{*}{53} & \multirow{2}{*}{343} \\
\hline & $\mathbf{R}$ & CAGGATGGTCTTGAAGTCTG & & \\
\hline \multirow{2}{*}{ AFP } & $\mathbf{F}$ & CAGAAAAATGGCAGCCACAGC & \multirow{2}{*}{54} & \multirow{2}{*}{399} \\
\hline & $\mathbf{R}$ & TGGCAGCATTTCTCCAACAGG & & \\
\hline \multirow{2}{*}{ ACTC1 } & $\mathbf{F}$ & CATCCTGACCCTGAAGTATCCCATC & \multirow{2}{*}{56} & \multirow{2}{*}{315} \\
\hline & $\mathbf{R}$ & CССTCATAGATGGGGACATTGTGAG & & \\
\hline \multirow{2}{*}{ SOX1 } & $\mathbf{F}$ & CCAGGAGAACCCCAAGAGGC & \multirow{2}{*}{56} & \multirow{2}{*}{206} \\
\hline & $\mathbf{R}$ & CGGCCAGCGAGTACTTGTCC & & \\
\hline \multirow{2}{*}{ ACTB ( $\beta$-actin) } & $\mathbf{F}$ & GCCACGGCTGCTTCCAGC & \multirow{2}{*}{55} & \multirow{2}{*}{477} \\
\hline & $\mathbf{R}$ & AGGGTGTAACGCAACTAAGTC & & \\
\hline
\end{tabular}

(a)

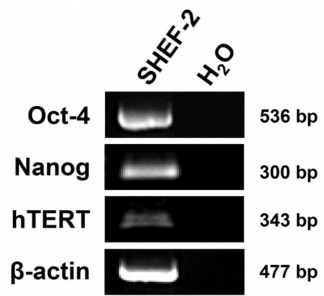

(b)

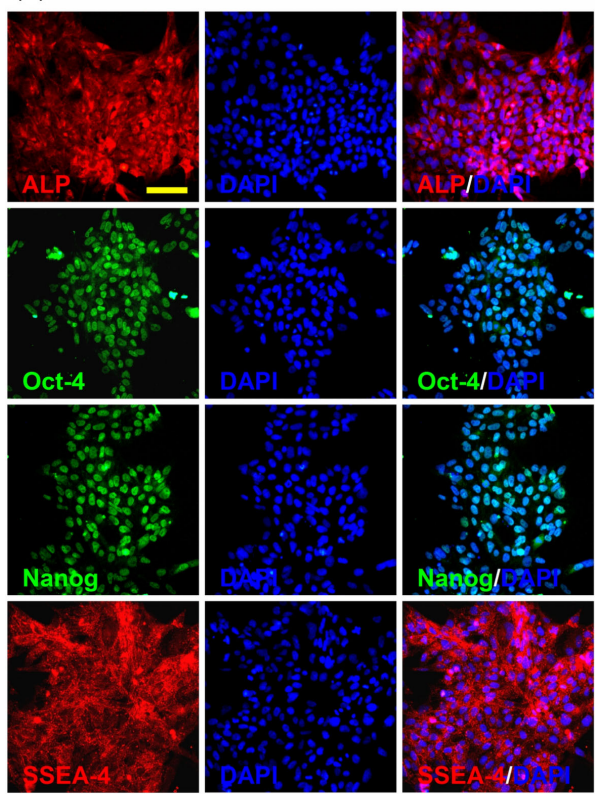

Figure 1. Pluripotent marker profile in SHEF-2. (a) mRNA expression for Oct-4, Nanog and hTERT was detected in undifferentiated hESC, SHEF-2 by RT-PCR. $\beta$-actin was the housekeeping gene; (b) Fluorescence immunocytochemistry shows SHEF-2 cells were positive for pluripotent marker proteins ALP, Oct-4, Nanog and SSEA-4 expression. Nuclear counter staining with DAPI. Scale bar, $100 \mu \mathrm{m}$. 
undifferentiated hESC secretome on AEC injury repair, two sets of conditioned media (CM), namely, CM ${ }^{\text {bFGF+ }}$ (with bFGF) and $\mathrm{CM}^{\mathrm{bFGF}-}$ (without bFGF) were prepared from adherent cultures of undifferentiated SHEF-2 cells. Corresponding controls media sets were $\mathrm{Un}-\mathrm{CM}^{\mathrm{bFGF}+}$ and $\mathrm{Un}-\mathrm{CM}^{\mathrm{bFGF}-}$ respectively, which were unconditioned. $\mathrm{CM}^{\mathrm{bFGF}+}$ and $\mathrm{CM}^{\mathrm{bFGF}-}$ significantly inhibited AEC injury repair after 24 hours when compared with the wound repair rates of corresponding controls (83 $\pm 6 \% \mathrm{CM}^{\mathrm{bFGF}}$ vs. $99 \pm 2 \%$ control Un-CM ${ }^{\mathrm{bFGF}+}$, and $82 \pm 5 \%$ $\mathrm{CM}^{\mathrm{bFGF}-}$ Vs. $99 \pm 1 \%$ control Un-CM ${ }^{\text {bFGF- }} ; \mathrm{p}<0.01$ ) (Figure 2(a), Figure 2(b)).

\subsection{Activin-Directed Differentiated hESC Secretome Displays Differential AEC Wound Repair Effects}

Next, we explored the effects of the Activin-directed differentiated hESC secretome on AEC wound repair. SHEF-2 cells were differentiated by sequential serum (FBS) and Activin A (100 ng/ml) [30] [39] treatment through an EB suspension culture and CM was collected at different time points of differentiation (Figure 3). The composition of media and conditioning duration are tabulated in Table 1. CM collected on day 8 (Day-8 CM) significantly inhibited AEC wound repair after 24 hours when compared with control (positive control) (62 $\pm 15 \%$ vs. $90 \pm 14 \%$ positive control; $\mathrm{p}<0.05$ ) (Figure 4(a), Figure 4(b)). Day-16 CM and Day-22 CM also inhibited AEC wound repair (63 \pm 7\%, Day-16 CM and $52 \pm 6 \%$ Day-22 CM vs. $90 \pm 14 \%$ positive control; p < 0.05 for Day-16 CM and p < 0.01 for Day-22 CM) (Figure 4(a), Figure 4(b)). In contrast, Day-11 CM did not inhibit AEC wound repair in comparison to the positive control (86 $\pm 10 \%$ vs. $90 \pm 14 \%$ positive control); moreover, the AEC wound repair rate with Day-11 CM was significantly higher than that of Day-8 CM (p < 0.05), Day-16 CM ( $<$ 0.01) and Day-22 CM ( $<$ 0.01) treated samples (Figure 4(a), Figure 4(b)). This data suggests that differentiated hESC-mediated paracrine healing influence is variable in nature which depends upon their stages of in vitro differentiation. In our particular setting, Day-11 secretome displays a comparatively positive AEC wound repair effect.

\subsection{Day-11 CM of Differentiated hESC Promotes AEC Wound Repair via Stimulation of Cell Migration and Proliferation}

Successful epithelial wound repair requires cell spreading, migration and proliferation [5] [6]. As seen above, Day-11 CM stimulated AEC injury repair (Figure 4). Here, we investigated the motogenic and mitogenic effects of CM collected from different time-points of Activin-directed hESC differentiation on AEC injury repair by measurement of both internuclear distance and MTT assay, respectively. Internuclear distances, an established method for assessment of cell migration [42] [43], between AEC at the wound margins of Day-11 CM treated samples were 17\% and 20\% higher than that of Day-8 CM and Day-22 CM treated samples respectively (57.26 $\pm 5.87 \mu \mathrm{m}$ Day-11 CM vs. $47.41 \pm 2.84 \mu \mathrm{m}$ Day-8 CM; p < 0.05 and vs. $45.80 \pm 2.80$ m Day-22 CM; p < 0.01$)$ (Figure 5(a), Figure 5(c)). The internuclear distance was 14\% higher in Day-11 CM treated samples when compared with positive control (Figure 5(a), Figure 5(c)).

Next, the mitogenic effect of CM on AEC during in vitro injury repair was evaluated by the MTT cell proliferation assay. A 2-fold and 2.3-fold higher cell proliferation rate was noted with Day-11 CM treated AEC wound samples after 24 hours when compared to Day-8 CM and Day-22 CM treated samples, respectively (104 \pm 28\%, Day-11 CM vs. $51 \pm 24 \%$, Day-8 CM, and $45 \pm 3 \%$, Day-22 CM; p < 0.01) (Figure 5(b)). The AEC proliferation with Day-11 CM was also higher than that of the positive control $(\mathrm{p}<0.05)$. Taken together, we conclude that Day-11 CM stimulates AEC wound repair through combined motogenic and monogenetic mechanisms.

\subsection{Day-11 CM Was Collected from a Mixed Population of Endodermal and Mesodermal Differentiated hESC}

High concentrations of Activin directs ESC differentiation into endodermal and mesodermal derivatives and suppresses ectodermal differentiation [30] [39]. RT-PCR demonstrated strong expression of endodermal lineage-specific gene AFP ( $\alpha$-Fetoprotein) [48] and mesodermal lineage-specific gene ACTC1 (actin, alpha, cardiac muscle 1) [49] in the differentiated cell population of EBs obtained on Day 11 and Day 22 of differentiation (Figure 6(a)). Whereas, neuro-ectodermal lineage specific gene, SOX1 (sex determining region Y-box 1) [50] expression was not detected in the above samples (Figure 6(a)). Immunocytochemistry with a panel of pluripotent marker antibodies on Day-1 differentiated EBs showed a strong protein expression profile for ALP, Oct-4, Nanog and SSEA-4; and a weak expression profile for SSEA-1 (Figure 6(b)). On the other hand, the ex- 

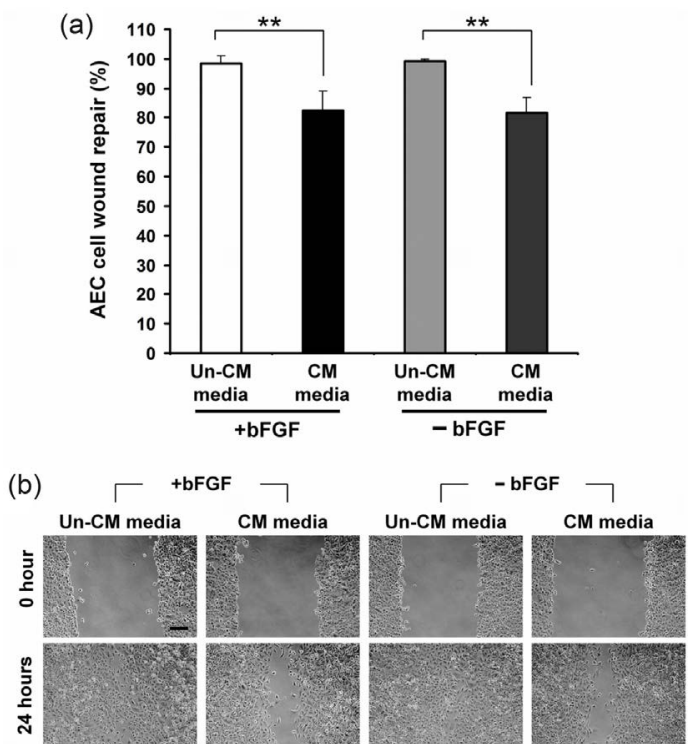

Figure 2. AEC injury repair with CM obtained from undifferentiated hESC. (a) AEC injury repair with two different sets of conditioned (CM) and corresponding un-conditioned (Un-CM) control media in presence or absence of bFGF after 24 hours; (b) Inverted light microscopy images of AEC injury repair with conditioned and un-conditioned media obtained from undifferentiated hESC. Data presented as mean \pm SD. $n=4$. $^{* *} \mathrm{p}<0.01$. Scale bar, $200 \mu \mathrm{m}$.

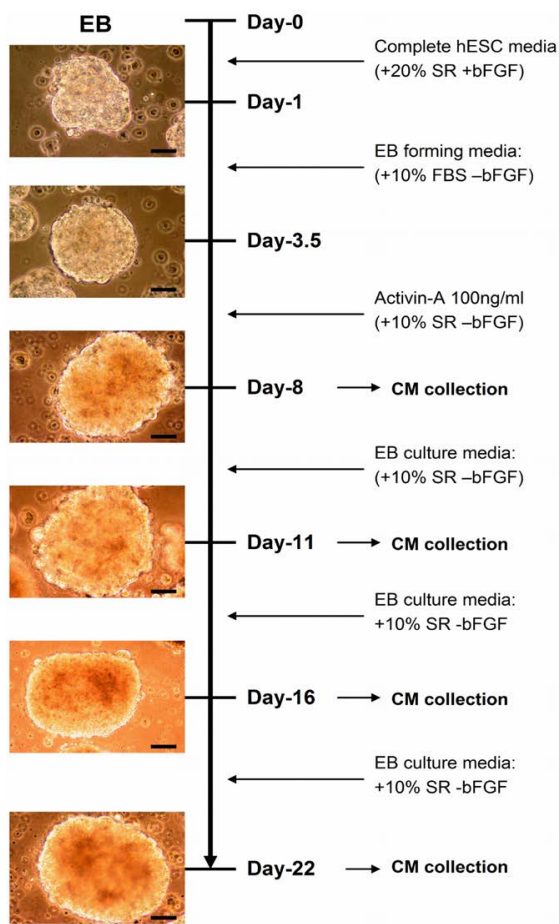

Figure 3. hESC differentiation with Activin and CM collection. Conditioned media (CM) were collected on 8th, 11th, 16th and 22nd day of differentiation. Images were captured on an inverted light microscope with attached CCD camera. Scale bar, $50 \mu \mathrm{m}$. 

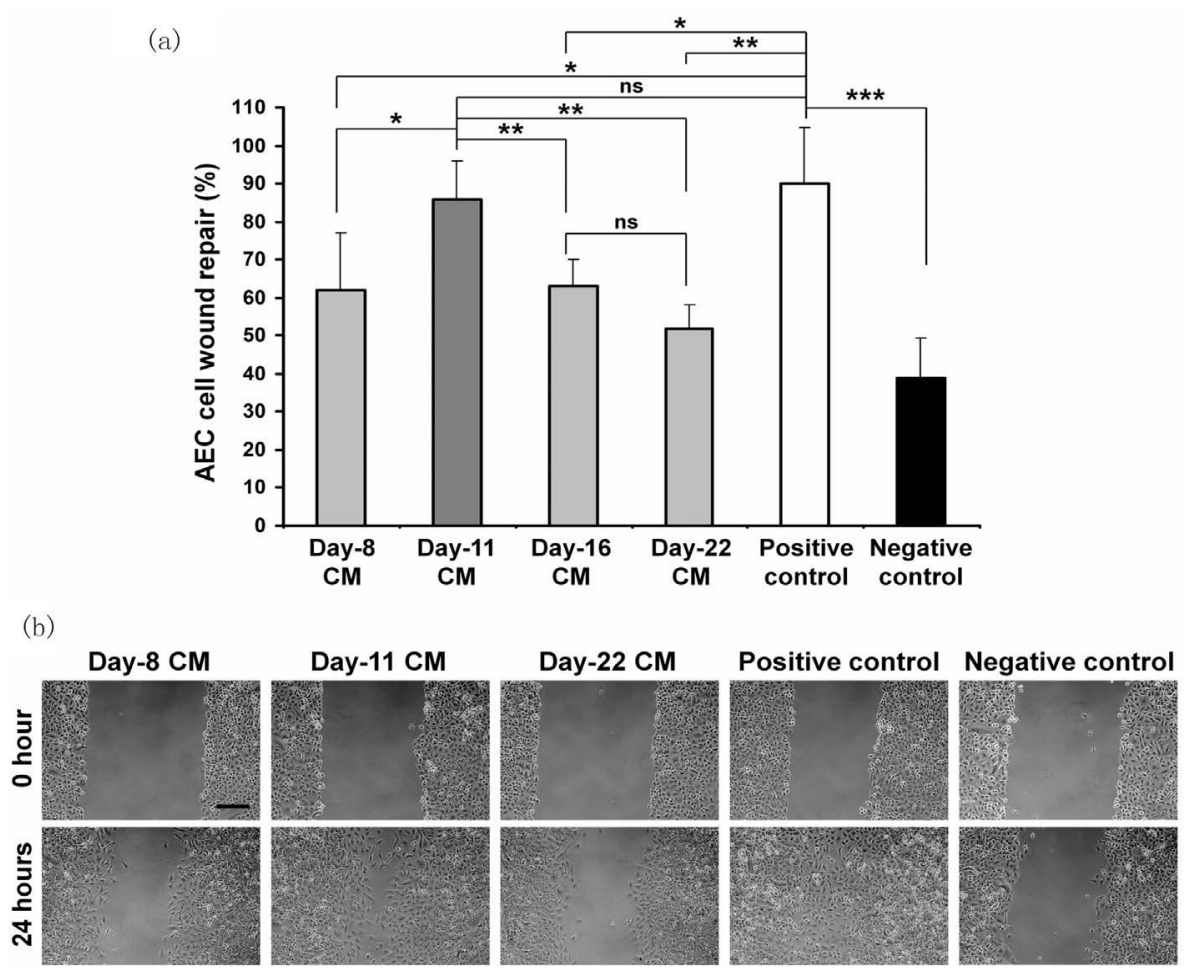

Figure 4. AEC wound repair with CM collected from differentiated hESC. (a) AEC wound repair after 24 hours with $\mathrm{CM}$ obtained from different time points of Activin-directed differentiated hESC through EB culture. Positive and negative controls represent AEC wound repair with $10 \% \mathrm{KO}$-SR supplemented KO-DMEM and KO-SR-free KO-DMEM respectively; both of these control media were un-conditioned; (b) Inverted light microscopic images of AEC wound repair with CM obtained from different time points of hESC differentiation. Data presented as mean $\pm \mathrm{SD}\left(\mathrm{n}=4\right.$, triplicate each time). ${ }^{*} \mathrm{p}<0.05,{ }^{* *} \mathrm{p}<0.01,{ }^{* * *} \mathrm{p}<0.001 . \mathrm{ns}=$ not significant. Scale bar, $200 \mu \mathrm{m}$.

pressions of above pluripotent marker proteins were very low (or negative) in the EBs obtained on Day 11 of differentiation (Figure 6(b)). These findings conclude that Day-11 CM contains secretory proteins from a differentiated mixed population of cells that predominantly consists of endodermal and mesodermal derivatives.

\section{Discussion}

Regenerative cell therapy for incurable lung diseases continues to evolve at a rapid pace. Preliminary studies suggested that adult stem cells, such as mesenchymal stem cells (MSC), might engraft to the injured lung, replace damaged epithelium and potentiate lung repair in animal models of COPD/emphysema, cystic fibrosis and IPF. However, it is now recognised that structural engraftment of MSC in lung is generally a rare occurrence with an uncertain fate of differentiation into alveolar epithelial cells [20]. A growing body of evidence suggests that the MSC-mediated lung repair effect largely occurs through paracrine mechanisms [51]-[55]. Unlike adult stem cells, ESC display enormous potential to differentiate into wide variety of cell types. Therefore, ESC are suggested as a suitable source of lung epithelial/progenitor cells for cell-based regenerative therapy for lung diseases. More recently, it has been reported that intratracheal administration of ESC-derived type II AEC ameliorated pulmonary inflammation and fibrosis in a bleomycin-induced experimental lung injury model; where, minimally, the early reparative response is mediated by a paracrine mechanism, although this paracrine effect has yet to be confirmed [40] [56]. Here, we have demonstrated that the secretome of differentiated hESC promotes alveolar epithelial cell wound repair via stimulation of cell migration and proliferation. This paracrine effect of cell-secretory products is specific to a particular stage of ESC differentiation, where the secretome collected on Day 11 of differentiation is found to be effective compared to that of pre- and post-Day 8-11 window in the repair of alveolar epithelial wound in vitro. 

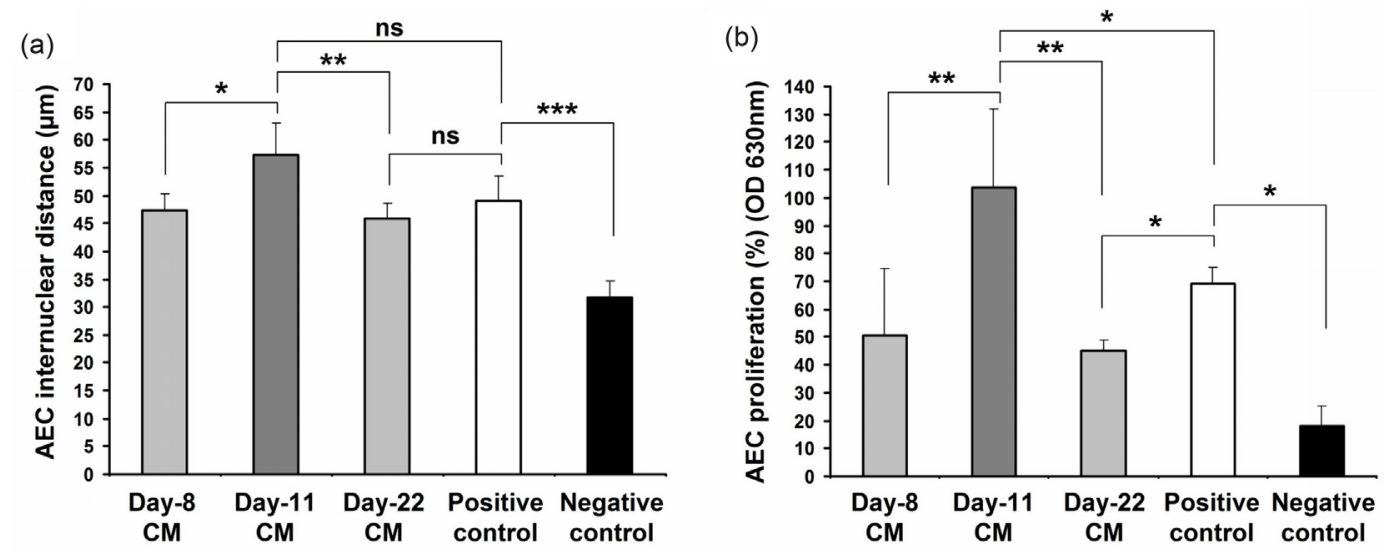

(c)
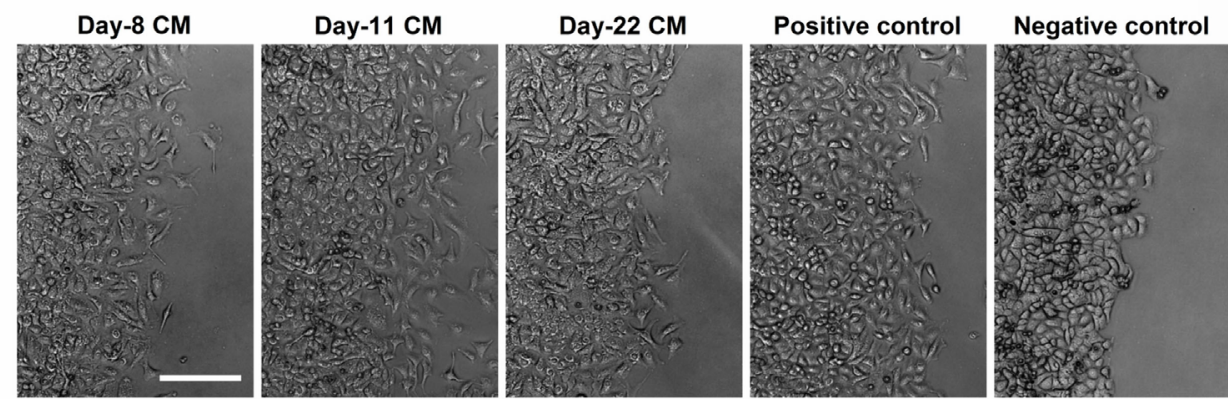

Figure 5. Assessment of internuclear distances and cell proliferation during AEC wound repair with CM of hESC differentiation. (a) Internuclear distances of AEC at the wound margins after 24 hours of wound repair with CM obtained from different time-points of Activin-directed differentiated hESC ( $\mathrm{n}=4$, a minimum of 40 measurements were recorded for each sample each time); (b) Rate of AEC proliferation after 24 hours with $\mathrm{CM}$ obtained from different time-points of hESC differentiation was determined by the colorimetric MTT assay $(n=3)$. Positive and negative controls represent AEC wound repair with $10 \%$ KO-SR supplemented KO-DMEM and KO-SR-free KO-DMEM respectively; both these control media were un-conditioned; (c) Representative inverted light microscopy images of AEC wound margins after 24 hours of treatment with CM and control media. Data presented as mean \pm SD. ${ }^{*} p<0.05,{ }^{* *} p<0.01$. ns $=$ not significant. Scale bar, $200 \mu \mathrm{m}$.

Data supportive of ESC-mediated paracrine influence in lung injury repair is lacking. However, infusion of mouse-ESC or ESC-conditioned media, as shown in the cardiac ischemia rat model, attenuated myocardial ischemia and improved cardiac function through a paracrine mechanism by ESC-secretory anti-inflammatory and cytoprotective cytokines, IL-10 and VEGF. In addition, transplantation of ESC suppressed pro-inflammatory cytokines TNF- $\alpha$, IL- 1 and IL-6 production by the injured cardiomyocytes [57]. Moreover, ESC paracrine protective mechanism in cardiac ischemia appeared superior to those of adult stem cells, as demonstrated by Crisostomo and colleagues [57]. Conditioned media obtained from undifferentiated pluripotent human ESC is stimulatory to neonatal cardiomyocyte proliferation [58]. ESC paracrine-mediated anti-apoptotic effects have also been demonstrated in cardiomyocytes and corneal endothelial cells in the in vitro culture system [59]-[61]. Conditioned media obtained from undifferentiated mouse ESC were capable of inhibiting $\mathrm{H}_{2} \mathrm{O}_{2}$-induced apoptosis in rat cardiomyocyte cell line H9c2 through ESC-secretory anti-apoptotic proteins cystatin c, osteopontin, clusterin and tissue inhibitor of metalloproteinase-1 (TIMP-1) via activation of PI3K/Akt signalling pathway [59] [60].

To date, ESC-paracrine effects were evaluated mostly by using undifferentiated ESC. In this study, however, approaches were taken to evaluate the motogenic and mitogenic paracrine effects of both undifferentiated and differentiated hESC on AEC injury repair in a controlled in vitro system. Surprisingly, our data demonstrates a negative regulatory effect of undifferentiated ESC-secretome on alveolar epithelial restitution. Although, the precise mechanism behind this negative wound repair effect was not investigated, it can be speculated that cell proliferation and/or migration were likely to be inhibited by undifferentiated hESC secretory proteins. In 


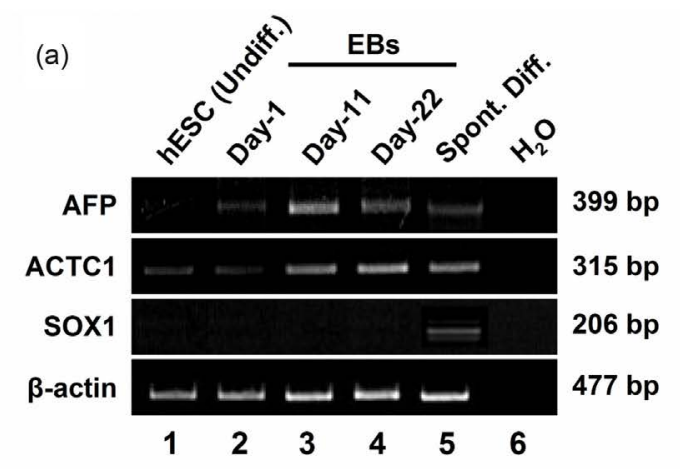

(b)

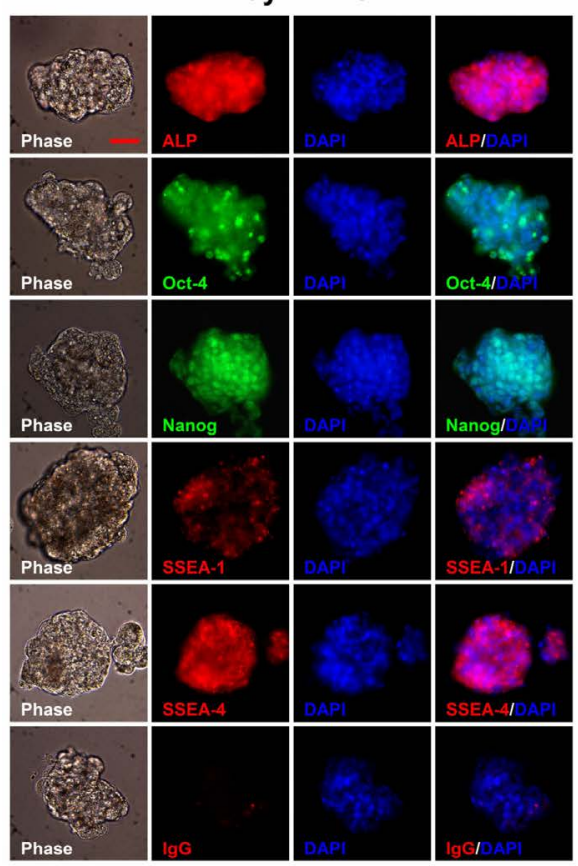

(c)

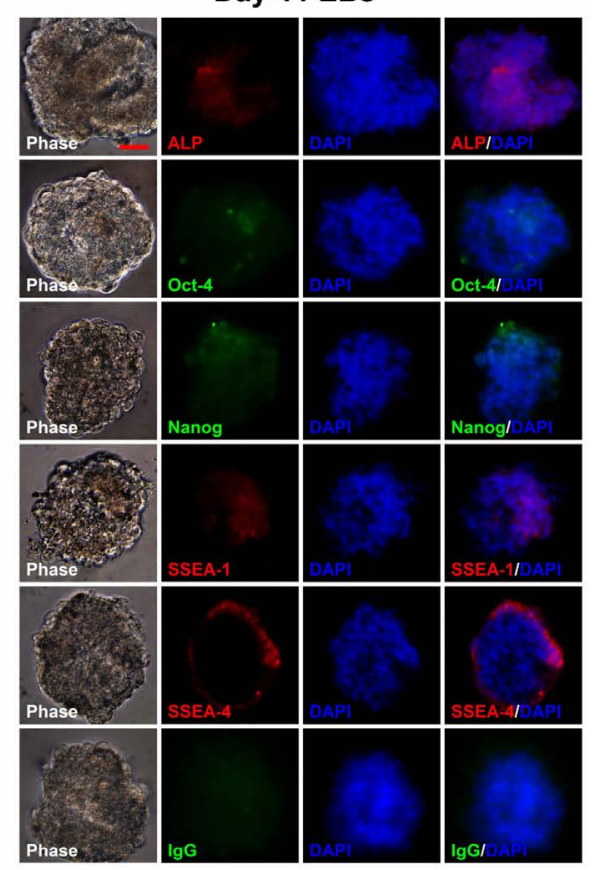

Figure 6. RT-PCR and fluorescence immunocytochemistry on EBs of differentiated hESC. (a) Semi-quantitative RT-PCR on differentiated EBs. Endodermal lineage-specific gene, AFP expression was detected on Day-11 and Day-22 differentiated EBs (lane-3, lane-4 respectively). AFP expression was not detected in undifferentiated hESC (lane-1) or spontaneously differentiated hESC (lane-5). Differentiated hESC on Day-11 (lane-3) and Day-22 (lane-4) expressed mesodermal specific gene, ACTC1. SOX1, an ectodermal specific gene, expression was not detected in our tested samples. $\beta$-actin was used as a house-keeping gene. (b, c) Fluorescence immunocytochemistry on Day-1 and Day-11 EBs with hESC pluripotent marker antibodies. IgG is for secondary antibody control. DAPI used for nuclear counterstaining. Scale bar, $50 \mu \mathrm{m}$.

general, restriction of mitogenic and/or motogenic mechanism could affect net epithelial wound repair. This is also supported by our observation where Day-22 CM of differentiated hESC significantly inhibited cell proliferation resulting in an inhibition of net AEC injury repair. Considering the LaFramboise et al. finding [58] coupled to our observation, it suggests that secretome of undifferentiated hESC may have a phenotype-specific mitogenic effect.

Moreover, the motogenic and mitogenic effects of differentiated hESC-secretome have appeared to be diverse in respect of AEC injury repair as well. The comparative analysis showed that only Day-11 CM (harvested from 8 - 11 day of differentiation) was effective in AEC injury repair; whereas, the CM collected on pre- and post day 8 - 11 window were inhibitory. In our study, CM were conditioned for a period of 3 - 5 days, therefore, it is not 
unlikely that culture media constituents of CM could be partially exhausted and might not match with constituents of positive control—a similar media without conditioning. However, our preliminary total protein quantitation by NanoDrop Spectrophotometry showed high protein contents in CM than positive control (data not shown). Moreover, our observation is that hESC do not grow properly without $10 \%$ KO-SR supplementation in the culture media, hence, was not possible to prepare CM with KO-SR free media. For this technical difficulties, in this study, we have prepared our CM with KO-SR supplemented media and drawn our conclusion only based on observed comparative wound repair effects in four different batches of CM collected on Day-8, -11, -16 and -22. Nonetheless, here, our careful observation provides at least an indication for selection of a cell-free ESC-derived soluble product therapy for pulmonary injury repair. Delay or failure of alveolar epithelial restitution is thought to play a major role in aberrant alveolar wound healing and fibrogenesis in IPF [2]. Histopathological findings show features of type II AEC hyperplasia, presumably due to reparative response. A recent study showed that targeted injury of type II AEC induced pulmonary fibrosis [62]. It follows that therapeutic intervention to facilitate type II AEC migration, proliferation and differentiation, could augment the reparative process of injured alveoli. More recently, it has been demonstrated that the milieu of damaged type II alveolar epithelial cells stimulates alveolar wound repair by autocrine and paracrine mechanism [63]. Herein, we report that ex vivo manipulation of hESC towards differentiation into endodermal and mesodermal derivatives provides a biological cue supportive of alveolar epithelial wound repair.

In this study, hESC were differentiated by restricted exposure of serum (FBS) followed by treatment with high concentration of recombinant human Activin A which, according to previously published data, generates cells of endodermal origin predominantly [30] [39]. However, in our study, differentiated cells within the EBs, particularly on day 11 and 22, expressed both endodermal and mesodermal specific genes. The similarity of this gene expression profile in differentiating EBs is also supported by the work of Rippon and colleagues [39]. Using a similar differentiation protocol but with mouse-ESC, Rippon et al. demonstrated that endodermal lineage-specific genes Foxa 2 and Sox 17 appeared to be highly expressed between 10 and 15 days of differentiation, whereas, distal lung progenitor marker TTF-1 and type II AEC-specific marker SPC gene expression appeared after 15 days of EB differentiation [39]. The mesodermal gene expression spiked on and after the 7th day of differentiation. The Rippon et al. findings combined with our data suggest that the secretome of Day 8-11 hESC differentiation is originated from a mixed population of endodermal and mesodermal derivatives.

Idiopathic pulmonary fibrosis is a chronic progressive lung disease leading to respiratory failure and early death. Alveolar epithelial cell damage (apoptosis) and failure of re-epithelialisation underpin IPF pathogenesis. Previously, ESC has been shown to have anti-apoptotic and anti-fibrotic effects; here we demonstrate their reepithelialisation stimulatory effect. Despite of our two consecutive approaches to identify the secretory proteins, responsible for wound healing, in the aforementioned CM and positive control by MS/MS Mass spectrometry we were unable to identify any wound-healing related human proteins, potentially, due to high KO-SR content in the media (data not shown). However, we anticipate developing a defined serum-free media to condition hESC and to test it on human primary lung epithelial cells using a more complex tissue-engineered in vitro wound-healing model and extend it to animal lung fibrosis model to reveal the detail paracrine mechanistic profile of ESC. Due to enormous differentiation potential, ESC has been proposed for clinical application of incurable lungs diseases [20]. However, potential risk of teratoma formation and graft rejection in the post-transplantation period are the major obstacles in the ESC-mediated cell therapy. Therefore, understanding their potential paracrine healing properties could be valuable, and perhaps, adaptable as an alternative to cell therapy in regenerative strategies.

\section{Acknowledgements}

This study was supported by a joint award through Medical Research Council Dorothy Hodgkin Postgraduate Award and the University Hospital of North Staffordshire Chest Charitable Fund.

\section{References}

[1] Raghu, G., Collard, H.R., Egan, J.J., et al. (2011) ATS/ERS/JRS/ALAT Committee on Idiopathic Pulmonary Fibrosis. An Official ATS/ERS/JRS/ALAT Statement: Idiopathic Pulmonary Fibrosis: Evidence-Based Guidelines for Diagnosis and Management. American Journal of Respiratory and Critical Care Medicine, 183, 788-824.

http://dx.doi.org/10.1164/rccm.2009-040GL 
[2] Selman, M., King, T.E. and Pardo, A. (2001) American Thoracic Society, European Respiratory Society, American College of Chest Physicians. Idiopathic Pulmonary Fibrosis: Prevailing and Evolving Hypotheses about Its Pathogenesis and Implications for Therapy. Annals of Internal Medicine, 134, 136-151. http://dx.doi.org/10.7326/0003-4819-134-2-200101160-00015.

[3] Strieter, R.M. (2005) Pathogenesis and Natural History of Usual Interstitial Pneumonia: The Whole Story or the Last Chapter of a Long Novel. Chest, 128, 526S-532S. http://dx.doi.org/10.1378/chest.128.5_suppl_1.526S

[4] Mason, R.J. (2006) Biology of Alveolar Type II Cells. Respirology, Suppl. 11, S12-S15. http://dx.doi.org/10.1111/j.1440-1843.2006.00800.x

[5] Zahm, J.M., Chevillard, M. and Puchelle, E. (1991) Wound Repair of Human Surface Respiratory Epithelium. American Journal of Respiratory Cell and Molecular Biology, 5, 242-248. http://dx.doi.org/10.1165/ajrcmb/5.3.242

[6] Puchelle, E., Zahm, J.M., Tournier, J.M., et al. (2006) Airway Epithelial Repair, Regeneration, and Remodeling after Injury in Chronic Obstructive Pulmonary Disease. Proceedings of the American Thoracic Society, 3, 726-733. http://dx.doi.org/10.1513/pats.200605-126SF

[7] Crosby, L.M. and Waters, C.M. (2010) Epithelial Repair Mechanisms in the Lung. AJP_Lung Cellular and Molecular Physiology, 298, L715-L731.

[8] Corrin, B., Dewar, A., Rodriguez-Roisin, R., et al. (1985) Fine Structural Changes in Cryptogenic Fibrosing Alveolitis and Asbestosis. The Journal of Pathology, 147, 107-119. http://dx.doi.org/10.1002/path.1711470206

[9] Uhal, B.D., Joshi, I., Hughes, W.F., et al. (1998) Alveolar Epithelial Cell Death Adjacent to Underlying Myofibroblasts in Advanced Fibrotic Human Lung. American Journal of Physiology_Lung Cellular and Molecular Physiology, 275, L1192-L1199.

[10] Kuwano, K., Miyazaki, H., Hagimoto, N., et al. (1999) The Involvement of Fas-Fas Ligand Pathway in Fibrosing Lung Diseases. American Journal of Respiratory Cell and Molecular Biology, 20, 53-60. http://dx.doi.org/10.1165/ajrcmb.20.1.2941

[11] Barbas-Filho, J.V., Ferreira, M.A., Sesso, A., et al. (2001) Evidence of Type II Pneumocyte Apoptosis in the Pathogenesis of Idiopathic Pulmonary Fibrosis (IFP)/Usual Interstitial Pneumonia (UIP). Journal of Clinical Pathology, 54, 132-138. http://dx.doi.org/10.1136/jcp.54.2.132

[12] Akram, K.M., Samad, S., Spiteri, M., et al. (2013) Mesenchymal Stem Cell Therapy and Lung Diseases. Advances in Biochemical Engineering/Biotechnology, 130, 105-29. http://dx.doi.org/10.1007/10_2012_140

[13] Akram, K.M., Lomas, N.J., Spiteri, M.A., et al. (2013) Club Cells Inhibit Alveolar Epithelial Wound Repair via TRAILDependent Apoptosis. European Respiratory Journal, 41, 683-694. http://dx.doi.org/10.1183/09031936.00213411

[14] Selman, M. and Pardo, A. (2002) Idiopathic Pulmonary Fibrosis: An Epithelial/Fibroblastic Cross-Talk Disorder. Respiratory Research, 3, 3. http://dx.doi.org/10.1186/rr175

[15] Odajima, N., Betsuyaku, T., Nasuhara, Y., et al. (2007) Loss of Caveolin-1 in Bronchiolization in Lung Fibrosis. Journal of Histochemistry \& Cytochemistry, 55, 899-909. http://dx.doi.org/10.1369/jhc.7A7203.2007

[16] Chilosi, M., Poletti, V., Murer, B., Lestani, M., Cancellieri, A., Montagna, L., et al. (2002) Abnormal Re-Epithelialization and Lung Remodeling in Idiopathic Pulmonary Fibrosis: The Role of $\Delta \mathrm{N}-\mathrm{p} 63$. Laboratory Investigation, 82, 1335-1345. http://dx.doi.org/10.1097/01.LAB.0000032380.82232.67

[17] Cisneros, J., Hagood, J., Checa, M., Ortiz-Quintero, B., Negreros, M., Herrera, I., et al. (2012) Hypermethylation-Mediated Silencing of p14ARF in Fibroblasts from Idiopathic Pulmonary Fibrosis. AJP, Lung Cellular and Molecular Physiology, 303, L295-L303.

[18] Hogaboam, C.M., Murray, L. and Martinez, F.J. (2012) Epigenetic Mechanisms through Which Toll-Like Receptor-9 Drives Idiopathic Pulmonary Fibrosis Progression. Proceedings of the American Thoracic Society, 9, 172-176. http://dx.doi.org/10.1513/pats.201201-002AW

[19] Rabinovich, E.I., Kapetanaki, M.G., Steinfeld, I., Gibson, K.F., Pandit, K.V., Yu, G., et al. (2012) Global Methylation Patterns in Idiopathic Pulmonary Fibrosis. PLOS ONE, 7, Article ID: e33770. http://dx.doi.org/10.1371/journal.pone.0033770

[20] Weiss, D.J. and Finck, C. (2010) Embryonic Stem Cells and Repair of Lung Injury. Molecular Therapy, 18, $460-461$. http://dx.doi.org/10.1038/mt.2010.8

[21] Evans, M.J. and Kaufman, M.H. (1981) Establishment in Culture of Pluripotential Cells from Mouse Embryos. Nature, 292, 154-156. http://dx.doi.org/10.1038/292154a0

[22] Kaufman, M.H., Robertson, E.J., Handyside, A.H. and Evans, M.J. (1983) Establishment of Pluripotential Cell Lines from Haploid Mouse Embryos. Journal of Embryology \& Experimental Morphology, 73, 249-261.

[23] Martin, G.R. (1981) Isolation of a Pluripotent Cell Line from Early Mouse Embryos Cultured in Medium Conditioned 
by Teratocarcinoma Stem Cells. Proceedings of the National Academy of Sciences of the United States of America, 78, 7634-7638. http://dx.doi.org/10.1073/pnas.78.12.7634

[24] Mummery, C., Ward, D., van den Brink, C.E., Bird, S.D., Doevendans, P.A., Opthof, T., et al. (2002) Cardiomyocyte Differentiation of Mouse and Human Embryonic Stem Cells. Journal of Anatomy, 200, 233-242. http://dx.doi.org/10.1046/j.1469-7580.2002.00031.x

[25] Mummery, C., Oostwaard, D.W., Doevendans, P., Spijker, R., van den Brink, S., Hassink, R., et al. (2003) Differentiation of Human Embryonic Stem Cells to Cardiomyocytes: Role of Coculture with Visceral Endoderm-Like Cells. Circulation, 107, 2733-2740. http://dx.doi.org/10.1161/01.CIR.0000068356.38592.68

[26] Ying, Q., Stavridis, M., Griffiths, D., Li, M. and Smith, A. (2003) Conversion of Embryonic Stem Cells into Neuroectodermal Precursors in Adherent Monoculture. Nature Biotechnology, 21, 183-186. http://dx.doi.org/10.1038/nbt780

[27] Shin, S., Dalton, S. and Stice, S.L. (2005) Human Motor Neuron Differentiation from Human Embryonic Stem Cells. Stem Cells and Development, 14, 266-269. http://dx.doi.org/10.1089/scd.2005.14.266

[28] Abranches, E., Silva, M., Pradier, L., Schulz, H., Hummel, O., Henrique, D., et al. (2009) Neural Differentiation of Embryonic Stem Cells in Vitro: A Road Map to Neurogenesis in the Embryo. PLoS ONE, 4, Article ID: e6286. http://dx.doi.org/10.1371/journal.pone.0006286

[29] D’Amour, K.A., Agulnick, A.D., Eliazer, S., Kelly, O.G., Kroon, E. and Baetge, E.E. (2005) Efficient Differentiation of Human Embryonic Stem Cells to Definitive Endoderm. Nature Biotechnology, 23, 1534-1541. http://dx.doi.org/10.1038/nbt1163

[30] Kubo, A., Shinozaki, K., Shannon, J.M., Kouskoff, V., Kennedy, M., Woo, S., et al. (2004) Development of Definitive Endoderm from Embryonic Stem Cells in Culture. Development, 131, 1651-1662. http://dx.doi.org/10.1242/dev.01044

[31] McLean, A.B., D’Amour, K.A., Jones, K.L., Krishnamoorthy, M., Kulik, M.J., Reynolds, D.M., et al. (2007) Activin A Efficiently Specifies Definitive Endoderm from Human Embryonic Stem Cells Only When Phosphatidylinositol 3Kinase Signaling Is Suppressed. Stem Cells, 25, 29-38. http://dx.doi.org/10.1634/stemcells.2006-0219

[32] Colman, A. (2004) Making New Beta Cells from Stem Cells. Seminars in Cell \& Developmental Biology, 15, $337-345$. http://dx.doi.org/10.1016/j.semcdb.2004.02.003

[33] Stoffel, M., Vallier, L. and Pedersen, R.A. (2004) Navigating the Pathway from Embryonic Stem Cells to Beta Cells. Seminars in Cell \& Developmental Biology, 15, 327-336. http://dx.doi.org/10.1016/j.semcdb.2004.02.002

[34] Hamazaki, T., Iiboshi, Y., Oka, M., Papst, P.J., Meacham, A.M., Zon, L.I., et al. (2001) Hepatic Maturation in Differentiating Embryonic Stem Cells in Vitro. FEBS Letters, 497, 15-19. http://dx.doi.org/10.1016/S0014-5793(01)02423-1

[35] Jones, E.A., Tosh, D., Wilson, D.I., Lindsaya, S. and Forrester, L.M. (2002) Hepatic Differentiation of Murine Embryonic Stem Cells. Experimental Cell Research, 272, 15-22. http://dx.doi.org/10.1006/excr.2001.5396

[36] Yamada, T., Yoshikawa, M., Kanda, S., Kato, Y., Nakajima, Y., Ishizaka, S., et al. (2002) In Vitro Differentiation of Embryonic Stem Cells into Hepatocyte-Like Cells Identified by Cellular Uptake of Indocyanine Green. Stem Cells, 20, 146-154. http://dx.doi.org/10.1634/stemcells.20-2-146

[37] Yamada, T., Yoshikawa, M., Takaki, M., Torihashi, S., Kato, Y., Nakajima, Y., et al. (2002) In Vitro Functional GutLike Organ Formation from Mouse Embryonic Stem Cells. Stem Cells, 20, 41-49. http://dx.doi.org/10.1634/stemcells.20-1-41

[38] Ali, N.N., Edgar, A.J., Samadikuchaksaraei, A., Timson, C.M., Romanska, H.M., Polak, J.M., et al. (2002) Derivation of Type II Alveolar Epithelial Cells from Murine Embryonic Stem Cells. Tissue Engineering, 8, 541-550. http://dx.doi.org/10.1089/107632702760240463

[39] Rippon, H.J., Polak, J.M., Qin, M. and Bishop, A.E. (2006) Derivation of Distal Lung Epithelial Progenitors from Murine Embryonic Stem Cells Using a Novel Three-Step Differentiation Protocol. Stem Cells, 24, 1389-1398. http://dx.doi.org/10.1634/stemcells.2005-0465

[40] Wang, D., Morales, J.E., Calame, D.G., Alcorn, J.L. and Wetsel, R.A. (2010) Transplantation of Human Embryonic Stem Cell-Derived Alveolar Epithelial Type II Cells Abrogates Acute Lung Injury in Mice. Molecular Therapy, 18, 625-634. http://dx.doi.org/10.1038/mt.2009.317

[41] Roszell, B., Mondrinos, M.J., Seaton, A., Simons, D.M., Koutzaki, S.H., Fong, G.H., et al. (2009) Efficient Derivation of Alveolar Type II Cells from Embryonic Stem Cells for in Vivo Application. Tissue Engineering Part A, 15, 33513365. http://dx.doi.org/10.1089/ten.tea.2008.0664

[42] Geiser, T., Jarreau, P.H., Atabai, K. and Matthay, M.A. (2000) Interleukin-1beta Augments in Vitro Alveolar Epithelial Repair. AJP, Lung Cellular and Molecular Physiology, 279, L1184-L1190.

[43] Atabai, K., Ishigaki, M., Geiser, T., Ueki, I., Matthay, M.A. and Ware, L.B. (2002) Keratinocyte Growth Factor Can Enhance Alveolar Epithelial Repair by Nonmitogenic Mechanisms. AJP, Lung Cellular and Molecular Physiology, 283, L163-L169. 
[44] Thomson, J.A., Itskovitz-Eldor, J., Shapiro, S.S., Waknitz, M.A., Swiergiel, J.J., Marshall, V.S., et al. (1998) Embryonic Stem Cell Lines Derived from Human Blastocysts. Science, 282, 1145-1147. http://dx.doi.org/10.1126/science.282.5391.1145

[45] Reubinoff, B.E., Pera, M.F., Fong, C.Y., Trounson, A. and Bongso, A. (2000) Embryonic Stem Cell Lines from Human Blastocysts: Somatic Differentiation in Vitro. Nature Biotechnology, 18, 399-404. http://dx.doi.org/10.1038/74447

[46] Chambers, I., Colby, D., Robertson, M., Nichols, J., Lee, S., Tweedie, S., et al. (2003) Functional Expression Cloning of Nanog, a Pluripotency Sustaining Factor in Embryonic Stem Cells. Cell, 113, 643-655. http://dx.doi.org/10.1016/S0092-8674(03)00392-1

[47] Mitsui, K., Tokuzawa, Y., Itoh, H., Segawa, K., Murakami, M., Takahashi, K., et al. (2003) The Homeoprotein Nanog Is Required for Maintenance of Pluripotency in Mouse Epiblast and ES Cells. Cell, 113, 631-642. http://dx.doi.org/10.1016/S0092-8674(03)00393-3

[48] Abe, K., Niwa, H., Iwase, K., Takiguchi, M., Mori, M., Abé, S.I., et al. (1996) Endoderm-Specific Gene Expression in Embryonic Stem Cells Differentiated to Embryoid Bodies. Experimental Cell Research, 229, 27-34. http://dx.doi.org/10.1006/excr.1996.0340

[49] Bruce, S.J., Gardiner, B.B., Burke, L.J., Gongora, M.M., Grimmond, S.M. and Perkins, A.C. (2007) Dynamic Transcription Programs during ES Cell Differentiation towards Mesoderm in Serum versus Serum-Free ${ }^{\text {BMP4 }}$ Culture. BMC Genomics, 8, 365. http://dx.doi.org/10.1186/1471-2164-8-365

[50] Pevny, L.H., Sockanathan, S., Placzek, M. and Lovell-Badge, R. (1998) A Role for SOX1 in Neural Determination. Development, 125, 1967-1978.

[51] Ortiz, L.A., Dutreil, M., Fattman, C., Pandey, A.C., Torres, G., Go, K., et al. (2007) Interleukin 1 Receptor Antagonist Mediates the Antiinflammatory and Antifibrotic Effect of Mesenchymal Stem Cells during Lung Injury. Proceedings of the National Academy of Sciences of the United States of America, 104, 11002-11007. http://dx.doi.org/10.1073/pnas.0704421104

[52] Zhen, G., Liu, H., Gu, N., Zhang, H., Xu, Y. and Zhang, Z. (2008) Mesenchymal Stem Cells Transplantation Protects against Rat Pulmonary Emphysema. Frontiers in Bioscience, 13, 3415-3422. http://dx.doi.org/10.2741/2936

[53] Burdon, T.J., Paul, A., Noiseux, N., Prakash, S. and Shum-Tim, D. (2011) Bone Marrow Stem Cell Derived Paracrine Factors for Regenerative Medicine: Current Perspectives and Therapeutic Potential. Bone Marrow Research, 2011, Article ID: 207326. http://dx.doi.org/10.1155/2011/207326

[54] Baber, S.R., Deng, W., Master, R.G., Bunnell, B.A., Taylor, B.K., Murthy, S.N., et al. (2007) Intratracheal Mesenchymal Stem Cell Administration Attenuates Monocrotaline-Induced Pulmonary Hypertension and Endothelial Dysfunction. AJP, Heart and Circulatory Physiology, 292, H1120-H1128.

[55] Nemeth, K., Keane-Myers, A., Brown, J.M., Metcalfec, D.D., Gorhamd, J.D., Bundoc, V.G., et al. (2010) Bone Marrow Stromal Cells Use TGF-Beta to Suppress Allergic Responses in a Mouse Model of Ragweed-Induced Asthma. Proceedings of the National Academy of Sciences of the United States of America, 107, 5652-5657. http://dx.doi.org/10.1073/pnas.0910720107

[56] Banerjee, E.R., Laflamme, M.A., Papayannopoulou, T., Kahn, M., Murry, C.E. and Henderson Jr., W.R. (2012) Human Embryonic Stem Cells Differentiated to Lung Lineage-Specific Cells Ameliorate Pulmonary Fibrosis in a Xenograft Transplant Mouse Model. PLoS ONE, 7, Article ID: e33165. http://dx.doi.org/10.1371/journal.pone.0033165

[57] Crisostomo, P.R., Abarbanell, A.M., Wang, M., Lahm, T., Wang, Y. and Meldrum, D.R. (2008) Embryonic Stem Cells Attenuate Myocardial Dysfunction and Inflammation after Surgical Global Ischemia via Paracrine Actions. AJP, Heart and Circulatory Physiology, 295, H1726-H1735.

[58] LaFramboise, W.A., Petrosko, P., Krill-Burger, J.M., Morris, D.R., McCoya, A.R., Scalise, D., et al. (2010) Proteins Secreted by Embryonic Stem Cells Activate Cardiomyocytes through Ligand Binding Pathways. Journal of Proteomics, 73, 992-1003. http://dx.doi.org/10.1016/j.jprot.2009.12.013

[59] Singla, D.K. and McDonald, D.E. (2007) Factors Released from Embryonic Stem Cells Inhibit Apoptosis of H9c2 Cells. AJP, Heart and Circulatory Physiology, 293, H1590-H1595.

[60] Singla, D.K., Singla, R.D. and McDonald, D.E. (2008) Factors Released from Embryonic Stem Cells Inhibit Apoptosis in H9c2 Cells through PI3K/Akt but Not ERK Pathway. AJP, Heart and Circulatory Physiology, 295, H907-H913.

[61] Lu, X., Chen, D., Liu, Z., Li, C., Liu, Y., Zhou, J., et al. (2010) Enhanced Survival in Vitro of Human Corneal Endothelial Cells Using Mouse Embryonic Stem Cell Conditioned Medium. Molecular Vision, 16, 611-622.

[62] Sisson, T.H., Mendez, M., Choi, K., Subbotina, N., Courey, A., Cunningham, A., et al. (2010) Targeted Injury of Type II Alveolar Epithelial Cells Induces Pulmonary Fibrosis. American Journal of Respiratory and Critical Care Medicine, 181, 254-263. http://dx.doi.org/10.1164/rccm.200810-1615OC

[63] Buckley, S., Shi, W., Carraro, G., Sedrakyan, S., Sacco, S.D., Driscoll, B.A., et al. (2011) The Milieu of Damaged Alveolar Epithelial Type 2 Cells Stimulates Alveolar Wound Repair by Endogenous and Exogenous Progenitors. Ameri- 
can Journal of Respiratory Cell and Molecular Biology, 45, 1212-1221. http://dx.doi.org/10.1165/rcmb.2010-03250C

[64] Xu, C., Inokuma, M.S., Denham, J., Golds, K., Kundu, P., Gold, J.D., et al. (2001) Feeder-Free Growth of Undifferentiated Human Embryonic Stem Cells. Nature Biotechnology, 19, 971-974. http://dx.doi.org/10.1038/nbt1001-971

[65] Plumb, J.A., Milroy, R. and Kaye, S.B. (1989) Effects of the pH Dependence of 3-(4,5-Dimethylthiazol-2-yl)-2,5-Diphenyl-Tetrazolium Bromide-Formazan Absorption on Chemosensitivity Determined by a Novel Tetrazolium-Based Assay. Cancer Research, 49, 4435-4440. 
Scientific Research Publishing (SCIRP) is one of the largest Open Access journal publishers. It is currently publishing more than 200 open access, online, peer-reviewed journals covering a wide range of academic disciplines. SCIRP serves the worldwide academic communities and contributes to the progress and application of science with its publication.

Other selected journals from SCIRP are listed as below. Submit your manuscript to us via either submit@scirp.org or Online Submission Portal.
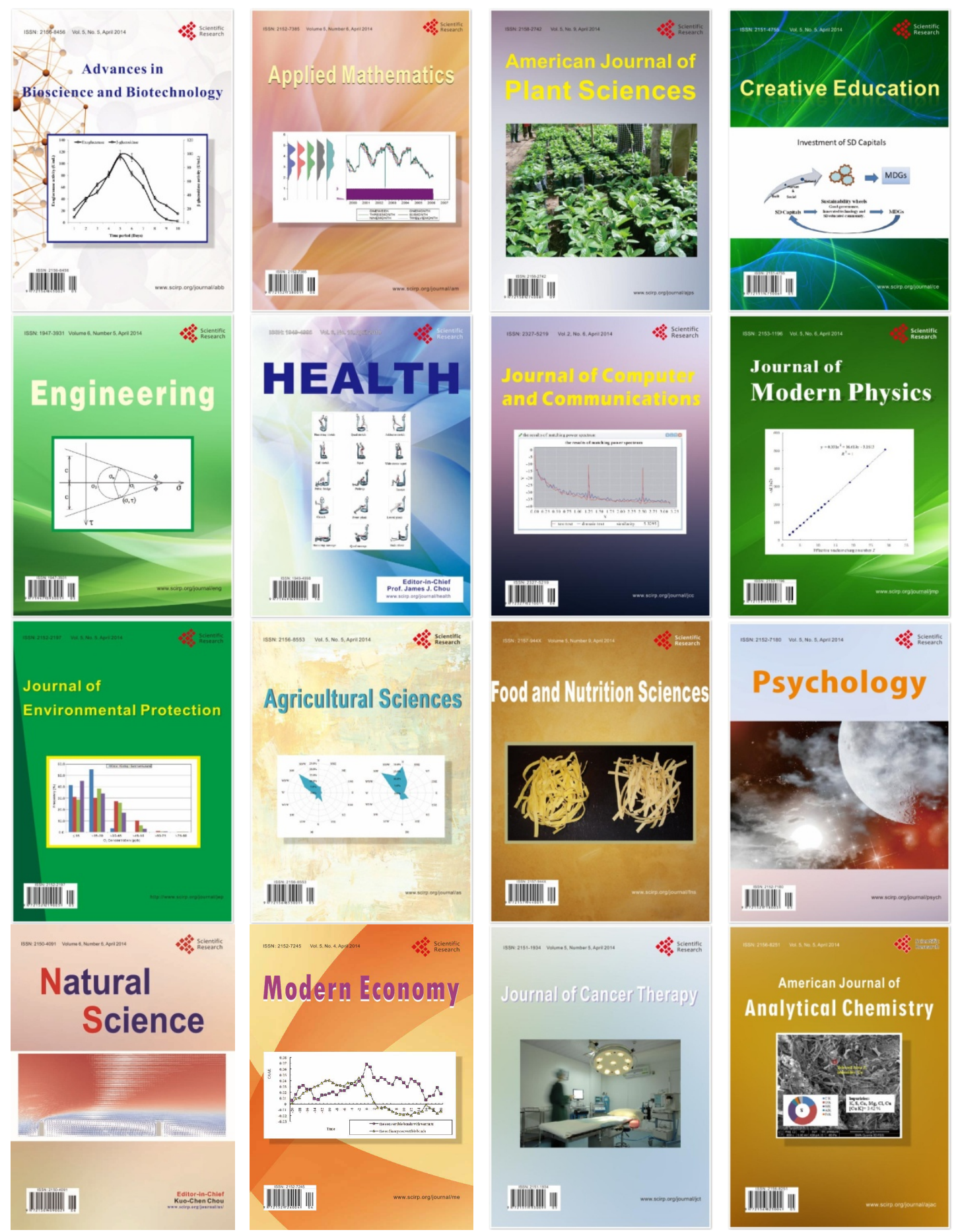